Pesq. Vet. Bras. 29(1):25-28, janeiro 2009

\title{
Identification of the recently described new type of bovine papillomavirus (BPV-8) in a Brazilian beef cattle herd ${ }^{1}$
}

\author{
Marlise P. Claus ${ }^{2}$, Michele Lunardi ${ }^{2}$, Alice F. Alfieri ${ }^{4}$, Daniele Sartori ${ }^{3}$, Maria \\ Helena P. Fungaro ${ }^{3}$ and Amauri A. Alfieri ${ }^{*}$
}

\begin{abstract}
Claus M.P., Lunardi M., Alfieri A.F., Sartori D., Fungaro M.H.P \& Alfieri A.A. 2009. Identification of the recently described new type of bovine papillomavirus (BPV-8) in a Brazilian beef cattle herd. Pesquisa Veterinária Brasileira 29(1):25-28. Laboratório de Virologia Animal, Departamento de Medicina Veterinária Preventiva, Centro de Ciências Agrárias, Universidade Estadual de Londrina, Cx. Postal 6001, Campus Universitário, Londrina, PR 86051-990, Brazil. E-mail: alfieri@uel.br

Bovine papillomavirus type 8 (BPV-8) was first detected and described in teat warts as well as in healthy teat skin from cattle raised in Japan. The entire viral genome was sequenced in 2007. Additionally, a variant of BPV-8, BPV-8-EB, was also identified from papillomatous lesions of a European bison in Slovakia. In Brazil, despite the relatively common occurrence of BPV infections, the identification and determination of viral types present in cattle is still sporadic. The aim of this study is to report the occurrence of the recently described BPV-8 in Brazil. The virus was identified in a skin warts obtained from a beef cattle herd located in Parana state, southern Brazil. The papilloma had a macular, non-verrucous gross aspect and was located on the dorsal thorax of a cow. Polymerase chain reaction (PCR) was performed using generic primers for partial amplification of L1 gene. The obtained amplicon (480bp) was cloned and two selected clones were sequenced. The nucleotide sequence was compared to existing papillomaviral genomic sequences, identifying the virus as BPV type 8 . This study represents the first report of BPV-8 occurrence in Brazil, what suggests its presence among Brazilian cattle.
\end{abstract}

INDEX TERMS: Bovine, bovine papillomavirus type 8, BPV-8, cutaneous papillomatosis, molecular analysis.

RESUMO.- [Identificação do novo tipo de papilomavírus bovino (BPV-8) recentemente descrito num rebanho bovino no Brasil.] A primeira descrição do papilomavírus bovino tipo 8 (BPV-8) foi realizada em amostras de papilomas de teto e de pele saudável de tetos de bovinos no Japão. Em 2007, a seqüência genômica completa do BPV-8 foi determinada. Ainda em 2007, uma variante do BPV-8 (BPV-8-EB) foi identificada em lesões papilomatosas de um bisão europeu na Eslováquia. No Brasil, apesar da infecção pelo BPV ser comumente observada em bovinos,

\footnotetext{
${ }^{1}$ Received on July $21,2008$.

Accepted for publication on August 1, 2008.

2,4 Laboratório de Virologia Animal, Departmento de Medicina Veterinária Preventiva, Universidade Estadual de Londrina, Cx.Postal 6001, Londrina, PR 86051-990, Brazil. *Corresponding author: alfieri@uel.br

${ }^{3}$ Faculdade de Biologia, Universidade Estadual de Londrina, Londrina, PR.
}

a determinação dos tipos virais associados com a infecção ainda é esporádica. Este estudo tem o objetivo de relatar a ocorrência do BPV-8 no país. A amostra clínica foi obtida em um rebanho de corte do estado do Paraná, região sul do Brasil. O papiloma cutâneo, de aspecto macular e nãoverrucoso, estava localizado na região dorsal torácica do animal. A identificação do vírus foi realizada pela reação em cadeia da polimerase (PCR) utilizando primers genéricos para a amplificação parcial do gene L1. O produto amplificado, com aproximadamente $480 \mathrm{pb}$, foi clonado e os fragmentos presentes em dois clones foram seqüenciados. A comparação da seqüência de nucleotídeos com a de outros papilomavírus demonstrou $100 \%$ de identidade com o BPV-8. Assim, esta é a primeira descrição da ocorrência do BPV-8 no Brasil, o que sugere a sua presença nos rebanhos bovinos brasileiros.

TERMOS DE INDEXAÇÃO: Bovino, papilomavírus bovino tipo 8, BPV-8, papilomatose cutânea, análise molecular. 


\section{INTRODUCTION}

In Brazil, bovine papillomavirus (BPV) infections are endemic in beef and dairy cattle throughout the country. Despite the high frequency of BPV infection, identification of BPV types in Brazilian cattle herds is still sporadic. By using specific primers, BPV type 1 was described in skin warts, peripheral blood and plasma from cattle with cutaneous papillomatosis, while BPV type 2 was detected in whole blood and urinary bladder tumors from cattle with chronic enzootic haematuria and cutaneous papillomatosis (Santos et al. 1998, Freitas et al. 2003, Wosiacki et al. 2005, 2006).

The partial analysis of L1 gene, the most conserved gene within the papillomaviral genome, by polymerase chain reaction (PCR) assay with degenerate primers and sequencing of amplicons has allowed a rapid identification of papillomavirus (PV) types as well as the detection of unreported viral types in human and animal hosts. A new PV type can be established once its complete genome has been cloned and its L1 gene displays less than $90 \%$ identity with the closest known PV type. A subtype is defined when the $L 1$ sequences show identities between 90 and 98\% (Manos et al. 1989, Forslund et al. 1999, Antonsson \& Hansson 2002, Ogawa et al. 2004).

While hundreds of human papillomavirus (HPV) types have been identified, only six BPV types had been characterized until the early 1980s (Jarret et al. 1984, Bernard 2005). However, recent studies employing PCR with generic primers FAP59/FAP64 in combination with cloning and sequencing, have described 15 putative new BPV types (Forslund et al. 1999, Antonsson \& Hansson 2002, Ogawa et al. 2004). After characterization of their complete genome sequences, four of these Japanese isolates were recently recognized as new viral types (BPV7, -8, -9, and -10) (Ogawa et al. 2007, Tomita et al. 2007, Hatama et al. 2008). In addition, four putative new BPV types have been identified in cutaneous lesions from cattle herds in Parana state, Brazil (Claus et al. 2008).

In 2007, the complete genome sequence of BPV type 8 (GenBank accession number: DQ098913) was determined. Based on the FAP59/FAP64 amplicon sequence, this virus was previously designated as a putative new BPV type, named BAPV2, by the same research group (Ogawa et al. 2004). BPV-8 was first detected from papillomas as well as healthy teat skin from cattle in Japan. In addition, the BPV-8-EB, a variant of BPV-8, was detected in papillomatous lesions of a European bison from Slovakia, demonstrating that this new BPV type was present, simultaneously, in Asia and Europe (Literák et al. 2006, Tomita et al. 2007).

The aim of the current study is to report the first identification of BPV-8 in Brazil, what suggests its occurrence throughout Brazilian cattle herds.

\section{MATERIALS AND METHODS}

\section{Papilloma specimen}

The papilloma specimen was collected from a cow in a beef cattle herd in the Parana state, southern Brazil. The macular, non-verrucous, cutaneous papilloma was located on the dorsal thorax of a cow. The skin wart was collected and the fragment of papilloma specimen was triturated in phosphate buffered saline solution (PBS pH 7.2). The suspension (10\% w/v) was centrifuged for $15 \mathrm{~min}$ at $3000 \times g$ at $4^{\circ} \mathrm{C}$. An aliquot $(250 \mu \mathrm{l})$ of the supernatant was treated with lysis buffer (10mM Tris; $1 \mathrm{mM}$ ethylenediamine tetra-acetic acid [EDTA]; 0.5\% Nonidet P40; $1 \%$ SDS; $0.2 \mathrm{mg} / \mathrm{ml}$ proteinase $\mathrm{K}$ ). After homogenization, the sample was incubated at $56^{\circ} \mathrm{C}$ for $30 \mathrm{~min}$.

\section{DNA extraction}

A combination of phenol/chloroform/isoamyl alcohol and silica/guanidine isothiocyanate methods was performed for extraction of total DNA (Alfieri et al. 2006). Briefly, the fraction of supernatant was treated with an equal volume of phenol/ chloroform/isoamyl alcohol (25:24:1), homogenized and heated at $56^{\circ} \mathrm{C}$ for $15 \mathrm{~min}$ (Sambrook \& Russell 2001). After centrifugation at $10,000 \times \mathrm{g}$ for $10 \mathrm{~min}$, the aqueous phase was mixed with silica/guanidine isothiocyanate (Boom et al. 1990). The DNA was eluted in $50 \mu$ of ultrapure sterile water and kept at $-20^{\circ} \mathrm{C}$ until use. An aliquot of ultrapure sterile water was included as negative control in the DNA extraction procedure.

\section{PCR assay}

The PCR assay was performed using the primers FAP59 (forward; 5'-TAACWGTIGGICAYCCWTATT-3') and FAP64 (reverse; 5'-CCWATATCWVHCATITCICCATC-3') (Forslund et al. 1999) with slight modifications (Claus et al. 2007). Reaction was carried out in a solution containing $5 \mu \mathrm{l}$ of the extracted DNA and $45 \mu \mathrm{l}$ of PCR-mix consisting of $1 \mu \mathrm{l}(20 \mathrm{pmol})$ of each primer; $200 \mu \mathrm{M}$ of each deoxyribonucleotide triphosphate (dNTP); 2.5 units of Platinum Taq DNA polymerase (Invitrogen Life Technologies, USA); 1x PCR buffer (20mM Tris- $\mathrm{HCl} \mathrm{pH}$ $8.4,50 \mathrm{mM} \mathrm{KCl}) ; 1.5 \mathrm{mM} \mathrm{MgCl}$, and ultrapure sterile water, to a final volume of $50 \mu \mathrm{l}$. Amplification was performed in a thermocycler, using the following amplification conditions: an initial step of $10 \mathrm{~min}$ at $94^{\circ} \mathrm{C}$ followed by 40 cycles of $1 \mathrm{~min}$ at $94^{\circ} \mathrm{C} ; 1 \mathrm{~min}$ at $50^{\circ} \mathrm{C}$, and $1 \mathrm{~min}$ at $72^{\circ} \mathrm{C}$, and a final extension step of $10 \mathrm{~min}$ at $72^{\circ} \mathrm{C}$. The amplified product was analyzed by electrophoresis in a $2 \%$ agarose gel in TBE buffer $\mathrm{pH} 8.4(89 \mathrm{mM}$ Tris; $89 \mathrm{mM}$ boric acid; $2 \mathrm{mM}$ EDTA) at constant voltage (90V) for approximately $45 \mathrm{~min}$, stained with ethidium bromide $(0.5 \mu \mathrm{g} /$ $\mathrm{ml}$ ), and visualized under UV light.

\section{Cloning and identity analysis}

The PCR amplicon was purified (PureLink Quick Gel Extraction Kit, Invitrogen Life Technologies, Carlsbad, CA, USA) from agarose gel and submitted to cloning (TOPO TA Cloning Kit for Sequencing, Invitrogen Life Technologies, Carlsbad, CA, USA). The insert from two selected clones was sequenced according to the manufacturer's instructions (MegaBACE 1000/ Automated 96 Capillary DNA Sequencer, GE Healthcare, Little Chalfont, Bucks, UK). Sequencing was performed in both directions by using M13 forward and reverse primers (DYEnamic ET Terminator Cycle Sequencing Kit, Amersham Biosciences, Little Chalfont Buckinghamshire, UK).

Sequences were examined with the PHRED software for quality analysis of chromatogram readings. The sequences were accepted if their base quality was equal to or higher than 20. The consensus sequences were determined using the CAP3 software and sequence identity was verified with all sequences deposited in the GenBank using BLAST software (http:// 
www.ncbi.nlm.nih.gov/BLAST). The alignment was obtained with the aid of the BioEdit software (Hall 1999).

Phylogenetic tree was obtained by the Neighbour-joining method with the Kimura two-parameter distance estimate (Kimura, 1980), using MEGA version 3.1 program (Kumar et al. 2004). Statistical analysis of phylogenetic tree was determined by bootstrap method on 1000 replicates.

\section{RESULTS AND DISCUSSION}

A product of approximately $480 \mathrm{bp}$ was amplified from the cutaneous papilloma. The negative control for PCR amplification yielded no amplified product. The product was sequenced and a 429 bp nucleotide sequence (BPV-8: nt. 5.739-6.172) was deposited in GenBank (accession number EF635385 as BPV/BR-UEL1). In addition, by nucleotide sequence comparison, it was demonstrated that sequences from both clones were identical.

The sequence analysis of the BPV L1 fragment identified from the cutaneous wart (BPV/BR-UEL1) revealed a $100 \%$ identity with BPV-8 sequences from Asia and Europe strains (Fig.1). While BPV-8 was originally detected in both teat papillomas and healthy teat skin swabs in Japan (Ogawa et al. 2004), the BPV-8 Brazilian strain was identified in a different anatomical location

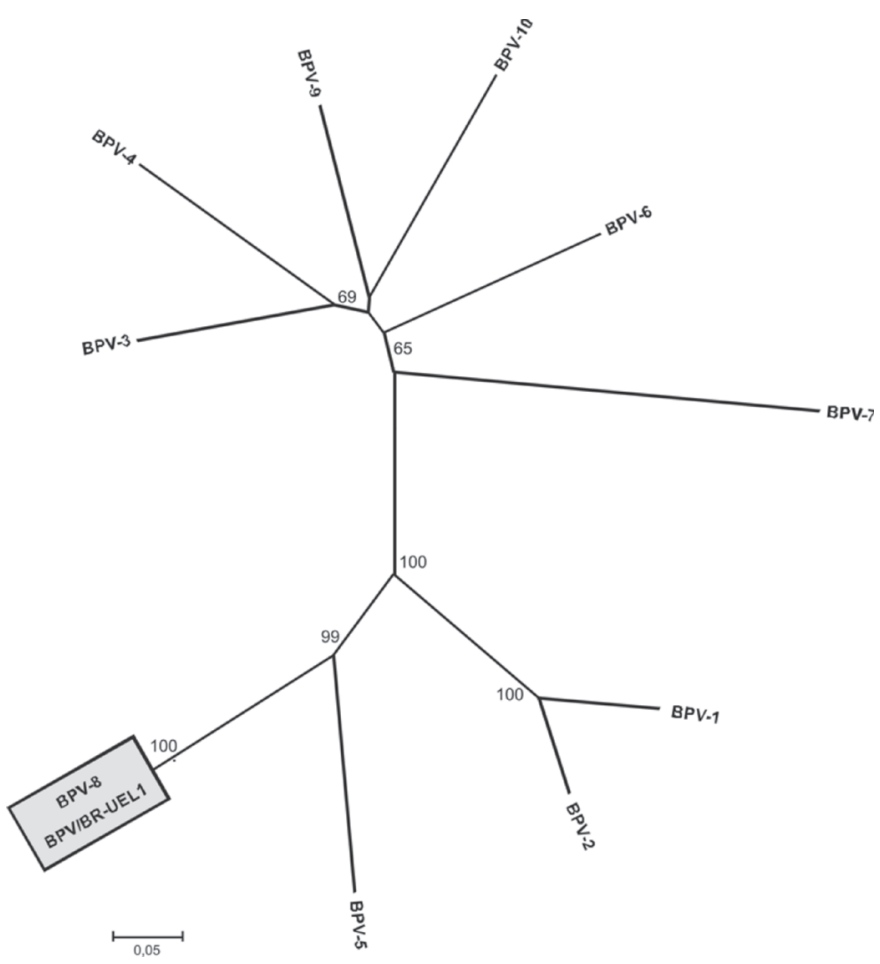

Fig.1. Neighbour-joining phylogenetic tree reconstructed with FAP sequences of BPV-BR/UEL1 isolate and previously described BPV types. The GenBank accession numbers of BPV types sequences are: XO2346 (BPV-1); M20219 (BPV2); AF486184 (BPV-3); XO5817 (BPV-4); AJ620206 (BPV5); AJ620208 (BPV-6); DQ217793 (BPV-7); DQ098913 (BPV-8); AB331650 (BPV-9); AB331651 (BPV-10). The numbers at internal nodes represent the bootstrap support values determined for 1000 replicates. (dorsal thorax). In agreement with the current findings, the variant of BPV-8, designated BPV-8-EB, was also identified in a non-teat papilloma in European bison (Literák et al. 2006, Tomita et al. 2007). These findings suggest that BPV8 does not have a predilection for a specific anatomical location.

Degenerate PCR primers with a high degree of nucleotide identity with conserved L1 gene have enabled the detection of a broad range of HPV types in a single round PCR assay (Manos et al. 1989, Forslund et al. 1999). These primers have also been applied to papillomas from animal species and have allowed the identification of putative new PV types. The use of FAP59 and FAP64 primers has also demonstrated the existence of a great diversity of BPV types (Antonsson \& Hansson 2002, Ogawa et al. 2004). Recently, by using the FAP primer pair, BPV types 1, 2, and 6 were identified in skin warts from cattle from Parana state (Claus et al. 2007). Besides, the detection of four putative new BPV types (BPV-BR/ UEL2 to -5), in Brazil, consisted the first report of the presence of different BPV types in the American continent (Claus et al. 2008).

Papillomavirus genomes seem to be very stable genetically and the occurrence of genetic changes, such as mutation or recombination, is an uncommon event. In addition, it is recognized that the HPV genome evolved with similar frequency to their host genome (De Villiers et al. 2004, Bernard 2005). The identification of BPV-8 in Asia (Japan), Europe (Slovakia), and South America (Brazil), within a short period of time, suggests the previous existence of this BPV type in these regions. It is possible that the presence of BPV-8 in Brazil had been ignored to date in the face of the scarce studies concerning the characterization of BPVs in the country. The result of the current study suggests that the low diversity observed in BPV (BPV-1 to BPV-10) to date may be due to the low number of viruses examined rather than due to a low diversity in the BPV genome. In addition, the detection of this viral type in Brazil points to its possible distribution throughout Brazilian cattle herds.

The recent researches in BPV suggest that this virus can be as diverse as HPV, and emphasize the importance of new investigations involving the molecular epidemiology of BPV infections in beef and dairy cattle herds around the world.

Acknowledgements.- To the Brazilian Institutes CNPq, CAPES, Finep, and Fundação Araucária (FAP/PR) for financial support. Amauri A. Alfieri, Alice F. Alfieri, and Maria Helena P. Fungaro are recipients of $\mathrm{CNPq}$ fellowships.

\section{REFERENCES}

Alfieri A.A., Parazzi M.E., Takiuchi E., Médici K.C. \& Alfieri A.F. 2006. Frequency of group A rotavirus in diarrhoeic calves in Brazilian cattle herds, 1998-2002. Trop. Anim. Health Prod. 38:521-526.

Antonsson A. \& Hansson B.G. 2002. Healthy skin of many species harbors papillomaviruses which are closely related to their human counterparts. J. Virol. 76(24):12537-12542. 
Bernard H.U. 2005. The clinical importance of the nomenclature, evolution and taxonomy of human papillomaviruses. J. Clin. Virol. 32:1-6.

Boom R., Sol C.J.A., Salimans M.M.M., Jansen C.L, Wertheim-Van Dillen P.M.E. \& Van Der Noordaa J. 1990. Rapid and simple method for purification of nucleic acids. J. Clin. Microbiol. 28:495-503.

Claus M.P., Vivian D., Lunardi M., Alfieri A.F. \& Alfieri A.A. 2007. Phylogenetic analysis of bovine papillomavirus associated with skin warts in cattle herds from the state of Parana. Pesq. Vet. Bras. 27(7):314-318.

Claus M.P., Lunardi M., Alfieri A.F., Ferracin L.M., Fungaro M.H.P. \& Alfieri A.A. 2008. Identification of unreported putative new bovine papillomavirus types in Brazilian cattle herds. Vet. Microbiol. 132:396401..

De Villiers E.-M., Fauquet C., Broker T.R., Bernard H.-U. \& Zur Hausen H. 2004. Classification of papillomaviruses. Virology 324:17-27.

Forslund O., Antonsson A., Nordin P. \& Hansson B.G. 1999. A broad range of human papillomavirus types detected with a general PCR method suitable for analysis of cutaneous tumours and normal skin. J. Gen. Virol. 80:2437-2443.

Freitas A.C., Carvalho C., Brunner O., Birgel-Jr E.H., Dellalibera A.M.M.P., Benesi F.J., Gregory L., Beçak W. \& Santos R.C.S. 2003. Viral DNA sequences in peripheral blood and vertical transmission of the virus: a discussion about BPV-1. Braz. J. Microbiol. 34:76-78.

Hall T.A. 1999. BioEdit: a user-friendly biological sequence alignment editor and analysis program for Windows 95/98/NT. Nucleic Acids Symposium 41:95-98.

Hatama S., Nobumoto K. \& Kanno T. 2008. Genomic and phylogenetic analysis of two novel bovine papillomaviruses, BPV-9 and BPV-10. J. Gen. Virol. 89:158-163.

Jarrett W.F.H., Campo M.S., O'Neil B.W., Laird H.M. \& Coggins L.W. 1984. A novel bovine papillomavirus (BPV-6) causing true epithelial papillomas of the mammary gland skin: a member of a proposed new BPV subgroup. Virology 136:255-264.

Kimura M. 1980. A simple method for estimating evolutionary rates of base substitution through comparative studies of nucleotide sequences. J. Mol. Evol. 16:111-120.

Kumar S., Tamura K. \& Nei M. 2004. MEGA3: integrated software for molecular evolutionary genetics analysis and sequence alignment. Brief. Bioinform. 5:150-163.

Literák I., Tomita Y., Ogawa T., Shirasawa H., Smíd B., Novotný L. \& Adamec M. 2006. Papillomatosis in a European bison. J. Wildl. Dis. 42:149-153.

Manos M.M., Ting Y., Wright D.K., Lewis A.J., Broker T.R. \& Wolinky S.M. 1989. The use of polymerase chain reaction amplification for the detection of genital human papillomaviruses. Cancer Cell 7:209-214.

Ogawa T., Tomita Y., Okada M., Shinozaki K., Kubonoya H., Kaiho I. \& Shirasawa H. 2004. Broad-spectrum detection of papillomaviruses in bovine teat papillomas and health teat skin. J. Gen. Virol. 85:21912197.

Ogawa T., Tomita Y., Okada M. \& Shirasawa H. 2007. Complete genome and phylogenetic position of bovine papillomavirus type 7. J. Gen. Virol. 88:1934-1938.

Sambrook J. \& Russell D.W. 2001. Molecular cloning: a laboratory manual. Cold Spring Harbor Laboratory, New York.

Santos R.C.S., Lindsey C.J., Ferraz O.P., Pinto J.R., Mirandola R.S., Benesi E.J., Birgel-Jr E.H., Pereira C.A.B. \& Beçak W. 1998. Bovine papillomavirus transmission and chromosomal aberrations: an experimental model. J. Gen. Virol. 79:2127-2135.

Tomita Y., Literák I., Ogawa T., Jin Z. \& Shirasawa H. 2007. Complete genomes and phylogenetic positions of bovine papillomavirus type 8 and a variant type from a European bison. Virus Genes 35:243-249.

Wosiacki S.R., Barreiros M.A.B., Alfieri A.F. \& Alfieri A.A. 2005. Seminested-PCR for detection and typing of bovine papillomavirus type 2 in urinary bladder and whole blood from cattle with enzootic haematuria. J. Virol. Methods 126:215-219.

Wosiacki S.R., Claus M.C., Alfieri A.F. \& Alfieri A.A. 2006. Bovine papillomavirus type 2 detection in the urinary bladder of cattle with chronic enzootic haematuria. Mem. Inst. Oswaldo Cruz 101:635-638. 